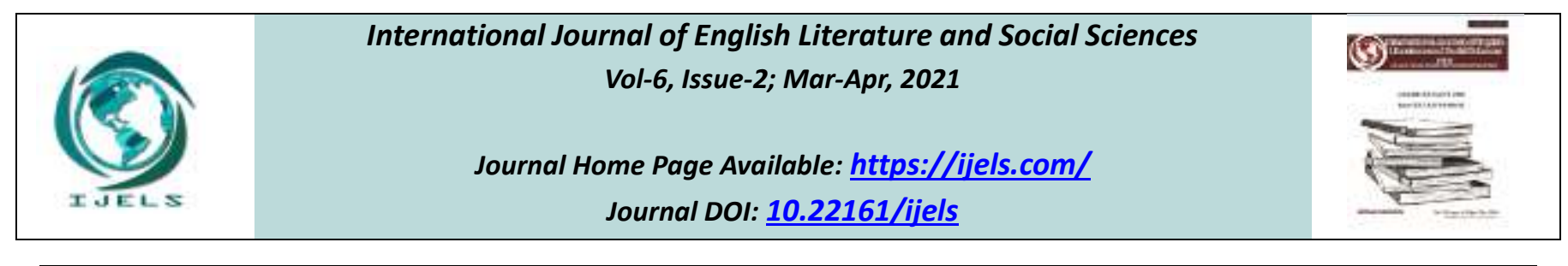

\title{
Evaluation on Water Safety Plan (WSP) in DWSSMG in Gringsing Sub District of Batang Regency
}

\author{
Edi Subagiyo ${ }^{1}$, Tri Joko ${ }^{2}$, Onny Setiani ${ }^{3}$ \\ ${ }^{1}$ Master of Environmental Health, Faculty of Public Health, Diponegoro University, Indonesia
${ }^{2,3}$ Lecturer in Faculty of Public Health, Diponegoro University, Indonesia
}

Received: 03 Dec 2020; Received in revised form: 09 Feb 2021; Accepted: 04 Mar 2021; Available online: 26 Mar 2021 (C2021 The Author(s). Published by Infogain Publication. This is an open access article under the CC BY license (https://creativecommons.org/licenses/by/4.0/).

\begin{abstract}
A safe water supply should fulfill quality, quantity, continuity, and accessibility and health requirement. The number of Drinking Water Supply and Sanitation Management Group (DWSSMG) at Village level increases continuously but the management of water security has not fulfilled the requirement. Drinking water scope is still a problem in Batang Regency particularly in five villages in Gringsing Sub District: Lebo (58.29\%), Madugowongjati (78\%), Sawangan (42.59\%), Surodadi (100\%), and Tedunan Villages (79.83\%). In addition tothe decrease in water quality (turbid), the total number of Coliform bacteria exceeds the threshold of standard drinking water quality according to Minister of Health's Regulation No.492/MENKES/PER/IV/ 2010.The objective of research is to find out the map of water safety risk based on quality, quantity, and continuity. The research method used was descriptive semi quantitative one using five-cell risk assessment technique referring to HACCP environmental management system. The sample of research consisted of 45 members of (DWSSMG) and 25 water sample points taken using total sampling technique. The result of assessment on quality-type risk shows 12 risks belonging to very high category, 14 belonging to medium, and 31 belonging to low category,while there is high risk in quantity type in Sawangan Village, 1 very high risk in continuity type in Sawangan Village, and no risk in accessibility type.
\end{abstract}

Keywords-Water safety plan, Drinking water, Risk Assessment, Hazardous event.

\section{INTRODUCTION}

Sustainable development goals (SDGs), in point 6.1, state that all States throughout world have agreed to ensure the safe drinking water universally, emphasizing on the importance of structural measure to prevent contamination from occurring in all water supplies. World Health Organization (WHO) introduces $3^{\text {rd }}$ edition of water safety manual called Water safety plan (WSP) ${ }^{1}$.Water safety management still becomes a problem in South East Asia, and it does so in Indonesia, where the drinking water safety fulfilling standard quality remains to be big challenge, and the achievement of drinking water health and basic sanitation indicators, according to Ministry of Health, is still below the target $(57.82 \%<80 \%)^{2}$. This condition encourages the feasible and safe drinking water supply to be a strategic issue.
The mandate of Medium-Term Development Plan (RPJMN) in 2020-2024 focuses on three basic frameworks: primary service, economic, and urban infrastructures. Infrastructural development for primary services is directed to bring even development distribution into reality throughout Indonesian areas. Primary service infrastructure that will be constructed involves providing access to feasible, safe, and affordable housing and settlement, access to water and sanitation (liquid waste and rubbish), sustainable groundwater and standard water management. The target of RPJMN in 2020-2024 toward SDGs 2030 is access to feasible water of $75.34 \%$ and to plumbing water of $30.45 \%$, while the access to feasible water now, based on National Social-Economic Survey of 2018 is $61.29 \%$, and access to piping in 2018 is $20.29 \%{ }^{3}$ 
Drinking water organization system (Indonesian: SPAM) has been governed based on Republic of Indonesia's Government Regulation Number 122 of 2015 stating that the implementation of water supply system organization is conducted by BUMN/BUMD (State/Local Governmentowned Enterprises), UPT/UPTD (Technical/Local Technical Service Units), community group or corporation $^{4}$. There are 380 SPAM organizers at regional level, distributed in all Indonesian cities, while there are 28,849 SPAMs at community level,called Drinking Water Supply and Sanitation Management Group (DWSSMG) in Pamsimas Program. There are 4,526 DWSSMGs in Central Java Province and 153 DWSSMGs in Batang Regency.

A safe water supply should meet physical, microbiological, chemical, and radioactive requirements ${ }^{54}$, detailing the parameter of water and supplement needed. An effective consistent method to ensure the water safety is comprehensive risk identification and assessment, as it involves all important measures related to water supply, from source to consumers ${ }^{6}-7$.

There are five DWSSMGs receiving SPAM construction grant through a Community-Based Water and Sanitation Supply Program (PAMSIMAS) in Lebo Village in 2010, Madugowongjati, Surodadi and Sawangan Villages in 2011, and Tedunan Village in 2019. Three villages use deep well basic water source, Sawangan village uses river as basic water, and Tedunan village uses water source as basic water distributed to consumers. In the last ten years (2010-2020) Lebo village is the one with little access to drinking water(58.29\%), Madugowongjati Village $(78 \%)$, Sawangan Village $(42.59 \%)$, Surodadi Village $(100 \%)$, and Tedunan Village $(79.83 \%)$. In addition, there is a change in water color or quality in Sawangan Village, and there is piping leakage in Lebo, Surodadi, and Sawangan Villages, and there is coliform bacterial contamination > 100 MPN in house plumbing,people complain with itchiness following using water in Sawangan Village. Considering the preliminary research, the objective of research is to find out the map of water safety risk based on quality, quantity, and continuity. in DWSSMG in Gringsing Sub District area of Batang Regency.

\section{METHOD}

The processes used in this study were initial observation, interview, and water quality testing in 25 critical points in five villages of Gringsing Sub District. Five (5) sample points were taken from each water reservoir, distributed water, and house plumbing in all villages using HACCP method, i.e. by analyzing the hazard with identification control point, and evaluating and controlling significant hazard to food security ${ }^{8}$. Water safety hazard was identified from the result of interview and questionnaire distributed to DWSSMG in Gringsing Sub District area of Batang Regency, Indonesia by applying Water Safety Plan model ( WHO) ${ }^{7}$.

This research employeda descriptive semi-quantitative case study with matrix approach and five-cell risk assessment format applying technical information and regulation ${ }^{91011}$. Different color background of categories representing the consequence severity is illustrated in table 1. With this semi-quantitative assessment, controlling measure can be controlled from the time when hazard occurs. The risk can be categorized by identifying the potential incidence and evaluating its consequence severity, as illustrated in table 2. Intersection is determined by hazard needing attention immediately. Risk should be assessed to distinguish the bigger hazardous event from the smaller one, so that the order of risk management priority can be developed and documented. It is important because despite many contaminants that can degrading water quality, not all hazards need the same attention ${ }^{7}$.The determination of risk size facilitates the process of evaluating a risk improving program, by seeing the change of risk score. The risk size is classified into four categories: very high category with risk score $\geq 15$, high category with risk score $=10-15$, and low category with risk score $<6$.

To develop the map of water safety risk in DWSSMGs in Gringsing Sub District of Batang Regency, ARC GIS 10.3 software was used. This mapping is intended to facilitate both organizers and stakeholders of Dinas Cipta Karyadan Permukiman(Work Creation and Settlement Service)to conduct building and to make policy. The result of identification is the portrait and condition of water safety in DWSSMG in Gringsing Sub District in 2020. Condition of water safety is classified into some colors: green or mild risk with score of $0-1$, moderate risk with score of 2-4, and high risk with score of 5-9. The higher the risk of water safety, the more hazardous is it to human health and it should be dealt with immediately and the organizer should improve water supply. 
Table.1 Matrix of Water Risk Assessment

\begin{tabular}{|c|c|c|c|c|c|c|c|}
\hline \multirow{3}{*}{$\begin{array}{l}\text { Probability of } \\
\text { incidence }\end{array}$} & \multicolumn{6}{|c|}{ Risk severity } & \multirow[t]{3}{*}{ Color definition } \\
\hline & & Very small & Small & Medium & Big & Very big & \\
\hline & & 1 & 2 & 3 & 4 & 5 & \\
\hline $\begin{array}{l}\text { Almost } \\
\text { always }\end{array}$ & 5 & 5 & 10 & 15 & 20 & 25 & 1-5 low (green) \\
\hline Often & 4 & 4 & 8 & 12 & 16 & 20 & $\begin{array}{l}6-9 \text { medium ( } \\
\text { yellow) }\end{array}$ \\
\hline Moderate & 3 & 3 & 6 & 9 & 12 & 15 & $\begin{array}{l}\text { 10-15 high risk } \\
\text { (orange) }\end{array}$ \\
\hline Small & 2 & 2 & 4 & 6 & 8 & 10 & $\begin{array}{l}\geq 16 \text { very high } \\
\text { (red) }\end{array}$ \\
\hline Very Small & 1 & 1 & 2 & 3 & 4 & 5 & \\
\hline
\end{tabular}

Table. 2 Water risk assessment scale

\begin{tabular}{lll}
\hline \multicolumn{2}{l}{ Incidence Probability Scale } & More than once a year \\
\hline 1 & Very rarely & Once a year \\
\hline 2 & Rarely & Monthly \\
\hline 3 & Moderately & Weekly \\
\hline 4 & Frequently & Daily \\
\hline Risk Severity Scale & Almost always & Undetected effect \\
\hline 1 & Very high & Affecting aesthetically the water, but it is still consumable \\
\hline 2 & High & \\
\hline 3 & Medium & Affecting aesthetically the water, and making the water \\
& & having taste and odor, and unsafe \\
\hline 4 & High & Resulting in illness among people \\
\hline 5 & Very high & Resulting in sudden death \\
\hline
\end{tabular}

\section{RESULT}

Risk assessment in this study involves water supplying system existing in five villages in Gringsing Sub District of Batang Regency of Central Java Province. Hazard identification and water safety risk assessment are conducted on the water coming from water source in reservoir, pipe, distribution, and plumbing in five villages in Gringsing Sub District of Batang Regency as illustrated in Figure 1.

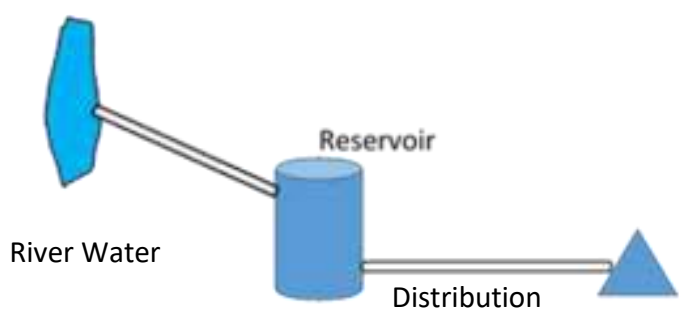

Fig.1. Plumbing System in Sawangan Village, Gringsing Sub District, Batang Regency, 2020

Table 3. Assessment of Water Safety Risk in Surodadi Village, Gringsing Sub District, Batang, 2020 


\begin{tabular}{|c|c|c|c|c|}
\hline No & Type of Hazardous event & Risk Assessment & $\begin{array}{l}\text { Color } \\
\text { Definition }\end{array}$ & Risk category \\
\hline $\mathrm{A}$ & Type of Quality K1 & & & \\
\hline \multirow[t]{6}{*}{1} & Primary Water Sourceof Reservoir & & & \\
\hline & a) Color Change in reservoir & 4 & & Low \\
\hline & b) Sediment on the bottom of reservoir & 4 & & Low \\
\hline & c) FecalContamination & 9 & & \\
\hline & d) Pathogenic contamination & 2 & & Low \\
\hline & e) Frequently dirty reservoir & 2 & & Low \\
\hline \multirow[t]{5}{*}{2} & Water source in distribution pipe & & & \\
\hline & a) Water leakage on distribution pipe & 9 & & Medium \\
\hline & b) Opened unplanted pipe on the ground & 4 & & Low \\
\hline & c) Non-hygienic plumbing handling & 4 & & Low \\
\hline & d) Water contamination due to leaked pipe & 9 & & Medium \\
\hline \multirow[t]{5}{*}{3} & Water source in consumer plumbing & & & \\
\hline & $\begin{array}{l}\text { a) Total coliform contamination in house } \\
\text { plumbing faucet }\end{array}$ & 16 & & Very High \\
\hline & b) Installation leakage in pipe meter & 4 & & Low \\
\hline & c) Poor quality of product or accessories & 4 & & Low \\
\hline & $\begin{array}{l}\text { d) Poor quality of house plumbing } \\
\text { installation }\end{array}$ & 4 & & Low \\
\hline B & Type of Quantity K2 & & & \\
\hline 1 & Decreased basic water flow rate & 4 & & Low \\
\hline 2 & $\begin{array}{l}\text { A large volume of domestic waste entering basic } \\
\text { water source }\end{array}$ & 4 & & Low \\
\hline 3 & $\begin{array}{l}\text { A large amount of weeds covering basic water } \\
\text { tapper }\end{array}$ & 4 & & Low \\
\hline 4 & $\begin{array}{l}\text { The change of water quality and quantity in rainy } \\
\text { season }\end{array}$ & 4 & & Low \\
\hline $\mathrm{C}$ & Type of Risk Continuity K3 & & & \\
\hline 1 & Water flows for $20-<24$ hours & 1 & & Low \\
\hline 2 & Water flows for $8-<24$ hours & & & \\
\hline 3 & Water flows for $4-5$ hours & & & \\
\hline 4 & Water does not flow for a (1) day & & & \\
\hline 5 & Water does not flow for $>$ a (1) day & & & \\
\hline $\mathbf{D}$ & Type of Accessibility Risk K4 & & & \\
\hline 1 & Water price is $<1 \%$ of people's income & 1 & & Low \\
\hline 2 & Water price is $1-4 \%$ of people's income & & & \\
\hline 3 & Water price is $4-6 \%$ of people's income & & & \\
\hline 4 & Water price is $6-8 \%$ of people's income & & & \\
\hline
\end{tabular}




\begin{tabular}{|c|c|c|c|c|}
\hline & & Risk Assessment & $\begin{array}{l}\text { Color } \\
\text { Definition }\end{array}$ & Risk category \\
\hline No & $\mathrm{y}_{1}$ & & & \\
\hline
\end{tabular}

$5 \quad$ Water price is $>8 \%$ of people's income

Table.4 Assessment of Water Safety Risk in Tedunan Village, Gringsing Sub District, Batang Regency, 2020

\begin{tabular}{|c|c|c|c|c|}
\hline No & Type of Hazardous event & $\begin{array}{l}\text { Early risk } \\
\text { assessment }\end{array}$ & $\begin{array}{l}\text { Color } \\
\text { definition }\end{array}$ & Category \\
\hline A & \multicolumn{4}{|l|}{ Type of Quality K1 } \\
\hline 1 & \multicolumn{4}{|l|}{ Reservoir basic water source } \\
\hline & a) Color change in reservoir & 4 & & Low \\
\hline & b) Sediment on the bottom of reservoir & 4 & & Low \\
\hline & c) Fecal contamination & 9 & & Medium \\
\hline & d) Pathogenic contamination & 2 & & Low \\
\hline & e) Frequently dirty reservoir & 2 & & Low \\
\hline
\end{tabular}

$2 \quad$ Water source in distribution pipe

a) Water leakage in distribution pipe $\quad 9 \quad$ Medium

b) Opened unplanted pipe in the ground 2 Low

c) Not-hygienic plumbing management 2 Low

d) Water contamination due to leaked pipe $3 \quad$ Medium

$3 \quad$ Water source in consumer plumbing

\begin{tabular}{|c|c|c|c|}
\hline & $\begin{array}{l}\text { a) Total Coliform contamination in house } \\
\text { plumbing faucet }\end{array}$ & 16 & Very High \\
\hline & b) Installation leakage in pipe meter & 4 & Low \\
\hline & $\begin{array}{l}\text { c) Poor quality of product or accessories } \\
\text { used }\end{array}$ & 4 & Low \\
\hline & d) Poor quality of house plumbing & 9 & Medium \\
\hline $\mathrm{B}$ & Type of Quantity K2 & & \\
\hline 1 & Decreased flow rate of basic water & 4 & Low \\
\hline 2 & $\begin{array}{l}\text { A large volume of domestic waste entering basic } \\
\text { water source }\end{array}$ & 4 & Low \\
\hline 3 & $\begin{array}{l}\text { A large amount of weeds covering basic water } \\
\text { tapper }\end{array}$ & 4 & Low \\
\hline 4 & $\begin{array}{l}\text { The change of water quality and quantity in rainy } \\
\text { season }\end{array}$ & 9 & Medium \\
\hline $\mathrm{C}$ & Type of Risk Continuity K3 & & \\
\hline 1 & Water flows for $20-<24$ hours & 1 & Low \\
\hline 2 & Water flows for $8-<24$ hours & & \\
\hline 3 & Water flows for $4-5$ hours & & \\
\hline
\end{tabular}




\begin{tabular}{|c|c|c|c|c|}
\hline No & Type of Hazardous event & $\begin{array}{l}\text { Early risk } \\
\text { assessment }\end{array}$ & $\begin{array}{l}\text { Color } \\
\text { definition }\end{array}$ & Category \\
\hline 5 & Water does not flow for $>$ a (1) day & & & \\
\hline $\mathbf{D}$ & Type of Accessibility Risk K4 & & & \\
\hline 1 & Water price is $<1 \%$ of people's income & 1 & & Low \\
\hline 2 & Water price is $1-4 \%$ of people's income & & & \\
\hline 3 & Water price is $4-6 \%$ of people's income & & & \\
\hline 4 & Water price is $6-8 \%$ of people's income & & & \\
\hline 5 & Water price is $>8 \%$ of people's income & & & \\
\hline
\end{tabular}

Table 5. Assessment of Water Safety Risk in Madugowongjati Village, Gringsing Sub District, Batang Regency, 2020

\begin{tabular}{|c|c|c|c|c|}
\hline No & Type of Hazardous event & $\begin{array}{l}\text { Early risk } \\
\text { assessment }\end{array}$ & $\begin{array}{l}\text { Color } \\
\text { definition }\end{array}$ & Category \\
\hline A & Type of Quality K1 & & & \\
\hline \multirow[t]{6}{*}{1} & Primary Water Source of Reservoir & & & \\
\hline & a) Color Change in reservoir & 4 & & Low \\
\hline & b) Sediment on the bottom of reservoir & 4 & & Low \\
\hline & c) Fecal Contamination & 6 & & Low \\
\hline & d) Pathogenic contamination & 4 & & Low \\
\hline & e) Frequently dirty reservoir & 4 & & Low \\
\hline \multirow[t]{5}{*}{2} & Water source in distribution pipe & & & \\
\hline & a) Water leakage on distribution pipe & & & \\
\hline & b) Opened unplanted pipe on the ground & 6 & & Low \\
\hline & c) Non-hygienic plumbing handling & 4 & & Low \\
\hline & d) Water contamination due to leaked pipe & 4 & & Low \\
\hline \multirow[t]{5}{*}{3} & Water source in consumer plumbing & 4 & & Low \\
\hline & $\begin{array}{l}\text { a) Total coliform contamination in house } \\
\text { plumbing faucet }\end{array}$ & & & \\
\hline & b) Installation leakage in pipe meter & 9 & & medium \\
\hline & c) Poor quality of product or accessories & 2 & & Low \\
\hline & d) Poor quality of house plumbing installation & 4 & & Low \\
\hline B & Type of Quantity K2 & & & \\
\hline 1 & Decreased flow rate of basic water & & & medium \\
\hline 2 & $\begin{array}{l}\text { A large volume of domestic waste entering basic } \\
\text { water source }\end{array}$ & 4 & & Low \\
\hline 3 & $\begin{array}{l}\text { A large amount of weeds covering basic water } \\
\text { tapper }\end{array}$ & 4 & & Low \\
\hline 4 & $\begin{array}{l}\text { The change of water quality and quantity in rainy } \\
\text { season }\end{array}$ & 4 & & Low \\
\hline $\mathrm{C}$ & Type of Risk K3 & & & \\
\hline
\end{tabular}




\begin{tabular}{|c|c|c|c|c|}
\hline No & Type of Hazardous event & $\begin{array}{l}\text { Early risk } \\
\text { assessment }\end{array}$ & $\begin{array}{l}\text { Color } \\
\text { definition }\end{array}$ & Category \\
\hline 1 & Water flows for $20-<24$ hours & 1 & & Low \\
\hline 2 & Water flows for $8-<24$ hours & & & \\
\hline 3 & Water flows for $4-5$ hours & & & \\
\hline 4 & Water does not flow for a (1) day & & & \\
\hline 5 & Water does not flow for $>$ a (1) day & & & \\
\hline $\mathbf{D}$ & Type of Accessibility Risk K4 & & & \\
\hline 1 & Water price is $<1 \%$ of people's income & 1 & & Low \\
\hline 2 & Water price is $1-4 \%$ of people's income & & & \\
\hline 3 & Water price is $4-6 \%$ of people's income & & & \\
\hline 4 & Water price is $6-81 \%$ of people's income & & & \\
\hline 5 & Water price is $>8 \%$ of people's income & & & \\
\hline
\end{tabular}

Tabel.6. Assessment of Water Safety Risk in Sawangan Village, Gringsing Sub District, Batang Regency, 2020

\begin{tabular}{|c|c|c|c|}
\hline No & Т & Color Definition & Category \\
\hline A & Type of Quality K1 & & \\
\hline \multirow[t]{6}{*}{1} & Primary Water Source of Reservoir & & \\
\hline & a) Color Change in reservoir & 16 & Very High \\
\hline & b) Sediment on the bottom of reservoir & 16 & Very High \\
\hline & c) Fecal Contamination & 9 & Medium \\
\hline & d) Pathogenic contamination & 16 & Very High \\
\hline & e) Frequently dirty reservoir & 16 & Very High \\
\hline \multirow[t]{5}{*}{2} & Water source in distribution pipe & & \\
\hline & a) Water leakage on distribution pipe & 16 & Very High \\
\hline & b) Opened unplanted pipe on the ground & 16 & Very High \\
\hline & c) Non-hygienic plumbing handling & 9 & Medium \\
\hline & d) Water contamination due to leaked pipe & 4 & Low \\
\hline \multirow[t]{5}{*}{3} & Water source in consumer plumbing & & \\
\hline & $\begin{array}{l}\text { a) Total coliform contamination in house } \\
\text { plumbing faucet }\end{array}$ & 16 & Very High \\
\hline & b) Installation leakage in pipe meter & 16 & Very High \\
\hline & c) Poor quality of product or accessories & 4 & Low \\
\hline & d) Poor quality of house plumbing installation & 9 & Medium \\
\hline B & Type of Quantity K2 & & \\
\hline 1 & Decreased basic water flow rate & 16 & Very High \\
\hline 2 & $\begin{array}{l}\text { A large volume of domestic waste entering basic } \\
\text { water source }\end{array}$ & 9 & Medium \\
\hline 3 & A large amount of weeds covering basic water & 4 & Low \\
\hline
\end{tabular}




\begin{tabular}{|c|c|c|c|}
\hline No & Trus f Horordous & Color Definition & Category \\
\hline & tapper & & \\
\hline 4 & $\begin{array}{l}\text { The change of water quality and quantity in } \\
\text { rainy season }\end{array}$ & 16 & Very High \\
\hline $\mathrm{C}$ & Type of Risk Continuity K3 & & \\
\hline 1 & Water flows for $20-<24$ hours & 1 & Low \\
\hline 2 & Water flows for $8-<24$ hours & & \\
\hline 3 & Water flows for $4-5$ hours & 16 & Very High \\
\hline 4 & Water does not flow for a (1) day & & \\
\hline 5 & Water does not flow for $>$ a (1) day & & \\
\hline $\mathbf{D}$ & Type of Accessibility Risk K4 & & \\
\hline 1 & Water price is $<1 \%$ of people's income & 1 & Low \\
\hline 2 & Water price is $1-4 \%$ of people's income & & \\
\hline 3 & Water price is $4-6 \%$ of people's income & & \\
\hline 4 & Water price is $6-8 \%$ of people's income & & \\
\hline 5 & Water price is $>8 \%$ of people's income & & \\
\hline
\end{tabular}

Table.7 Assessment of Water Safety Risk in Lebo Village, Gringsing Sub District, Batang Regency, 2020

\begin{tabular}{|c|c|c|c|}
\hline \multirow{2}{*}{ No } & \multirow{2}{*}{ Type of Hazardous event } & \multirow[b]{2}{*}{ Color Definition } & \multirow[b]{2}{*}{ Category } \\
\hline & & & \\
\hline A & Type of Quality K1 & & \\
\hline \multirow[t]{6}{*}{1} & Primary Water Source of Reservoir & & \\
\hline & a) Color Change in reservoir & 9 & Medium \\
\hline & b) Sediment on the bottom of reservoir & 16 & Very High \\
\hline & c) Fecal Contamination & 4 & Low \\
\hline & d) Pathogenic contamination & 4 & Low \\
\hline & e) Frequently dirty reservoir & 4 & Low \\
\hline \multirow[t]{5}{*}{2} & Water source in distribution pipe & & \\
\hline & a) Water leakage on distribution pipe & 9 & Medium \\
\hline & b) Opened unplanted pipe on the ground & 16 & Very High \\
\hline & c) Non-hygienic plumbing handling & 6 & Medium \\
\hline & d) Water contamination due to leaked pipe & 6 & Low \\
\hline \multirow[t]{5}{*}{3} & Water source in consumer plumbing & & \\
\hline & $\begin{array}{l}\text { a) Total coliform contamination in house plumbing } \\
\text { faucet }\end{array}$ & 16 & Very High \\
\hline & b) Installation leakage in pipe meter & 4 & Low \\
\hline & c) Poor quality of product or accessories & 4 & Low \\
\hline & d) Poor quality of house plumbing installation & 4 & Medium \\
\hline B & Type of Quantity K2 & & \\
\hline
\end{tabular}




\begin{tabular}{|c|c|c|c|}
\hline \multirow{2}{*}{ No } & \multirow{2}{*}{ Type of Hazardous event } & \multirow[b]{2}{*}{ Color Definition } & \multirow[b]{2}{*}{ Category } \\
\hline & & & \\
\hline 1 & Decreased basic water flow rate & 4 & Low \\
\hline 2 & $\begin{array}{l}\text { A large volume of domestic waste entering basic } \\
\text { water source }\end{array}$ & 4 & Medium \\
\hline 3 & A large amount of weeds covering basic water tapper & 4 & Low \\
\hline 4 & $\begin{array}{l}\text { The change of water quality and quantity in rainy } \\
\text { season }\end{array}$ & 4 & Low \\
\hline $\mathrm{C}$ & Type of Risk Continuity K3 & & \\
\hline 1 & Water flows for $20-<24$ hours & 1 & Low \\
\hline 2 & Water flows for $8-<24$ hours & & \\
\hline 3 & Water flows for $4-5$ hours & & \\
\hline 4 & Water does not flow for a (1) day & & \\
\hline 5 & Water does not flow for $>$ a (1) day & & \\
\hline $\mathbf{D}$ & Type of Accessibility Risk K4 & & \\
\hline 1 & Water price is $<1 \%$ of people's income & 1 & Low \\
\hline 2 & Water price is $1-4 \%$ of people's income & & \\
\hline 3 & Water price is $4-6 \%$ of people's income & & \\
\hline 4 & Water price is $6-8 \%$ of people's income & & \\
\hline 5 & Water price is $>8 \%$ of people's income & & \\
\hline
\end{tabular}

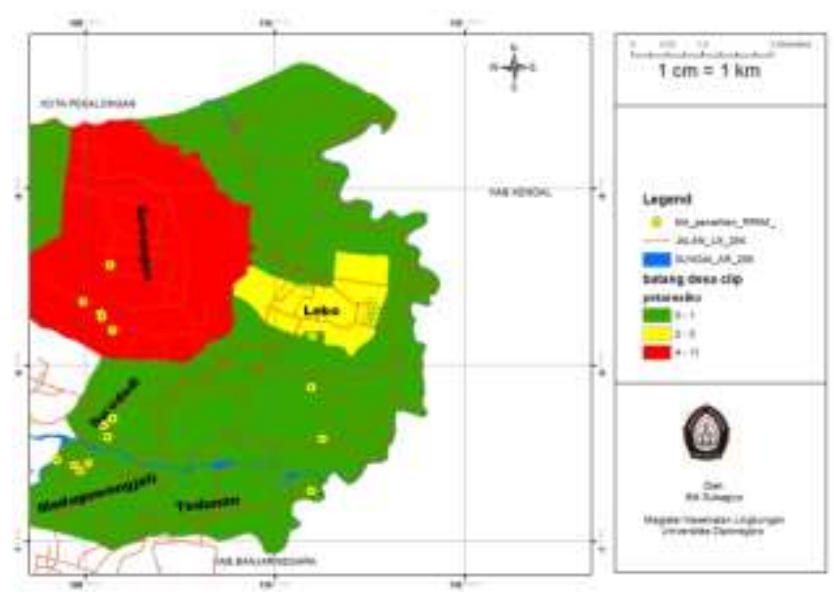

Fig.2: Map of Water Safety Risk in DWSSMG in Gringsing Sub District of Batang Regency in 2020

\section{DISCUSSION}

Drinking water, based on Minister of Health Regulation No.492/Menkes/PER/IV/2010 about the requirement of drinking water quality is the one passing through processing activity or without processing activity that complies with health condition and is drinkable. Meanwhile, safe water access is defined as household using feasible water source, in which water source is located either inside or outside the house (in the house yard), available anytime it is needed, and the quality of water used complies with the requirement of water quality in Indonesia ${ }^{12}$. Water Safety Plan is intended primarily to ensure quality, quantity, continuity, and accessibility.

The result of water safety risk assessment in Surodadi Village presented in Table1 shows very high category (red) in house plumbing in the presence of Coliform 85 MPN/100 Ml bacterium. It is because there is water meter leakage in house plumbing. Coliform is a class of 
Enterobacteriaceace bacterium. This class is defined as aerobic or optionally anaerobic. Total coliform is used to find the effectiveness and integrity of water processing. At certain condition, Coliformcan proliferate in water distribution system ${ }^{13}$. Standard piping water quality, based on PermenkesNo. 492 of 2010 about drinking water quality, is $0 \mathrm{MPN} / 100 \mathrm{ml}^{5}$. Meanwhile, the margin of standard clean water quality allowed based on Permenkes No. 32 of 2017 is $50 \mathrm{MPN} / 100 \mathrm{ML}^{14}$. The presence of pathogen and Coliform bacteria $85 \mathrm{MPN} / 100 \mathrm{Ml}$ in house plumbing indicates unqualified water quality. It will affect indirectly the health. The result of assessment indicates Medium risk category (yellow), in which there are distribution pipe leakage and contamination in the leaked pipe.

The result of assessment on water safety risk in Tedunan Village, as presented in Table 2, shows 1 (one) very high risk category with score $=16$, meaning that there is Coliform $132 \mathrm{MPN} / 100 \mathrm{ml}$ in house plumbing, 4 (four)medium risk categories in reservoir water source due to contamination, distribution pipe leakage, and contamination due to leaked pipe and poor quality of house plumbing installation, and 8 (eight) low risk categories. The contamination of Coliform bacterium in house plumbing is because the standard water source used is the one coming from mountains. Disinfection and chlorination processes have not been conducted yet by DWSSMG, so that water supply from water source is distributed directly to consumers. This condition enables bacteria coming frommanure to enter it. The presence of pathogenic and Coliform bacteriaindicates unsafe water quality ${ }^{5}$.

The assessment in Madugowongjati Village found 1 (one) medium risk category in total Coliform bacterial contamination of $39 \mathrm{MPN} / 100 \mathrm{ml}$ in consumer's plumbing or the end of SR. The presence of total coliform bacterium in piping installation is because of no water processing and disinfecting activity, thereby leading bacteria to potentially grow later. In this study, water safety plan (WSP) is defined as an attempt of securing water, either qualitatively or quantitatively. Quality aspect includes contamination prevention, while quantity aspect includes service accessibility to consumers.

In Sawangan there are 8(eight) very high risk categories, 4 (four) of whichare found in primary water source of reservoir (the change of water color in reservoir, sediment on the bottom of reservoir, pathogenic contamination, and frequently dirty reservoir), 2 (two) in distribution pipe water source (distribution pipe leakage and opened pipe), and 2 (two) in consumers' plumbing system (total coliform contamination and pipe meter installation leakage). Three (3) medium risk categories are found including 1 (one) risk in reservoir water source (fecal contamination) 1 (one) in distribution pipe, and 1 (one) in consumers' plumbing system due to less hygienic pipe installation. The result of identification and investigation on plumbing system along with the management indicates that color change event often occurs in reservoir during rainy season, basic water source coming from the river without processing activity is the main cause of it. Such condition is illustrated in figure 2. Primary water distribution system streams the water directly from the river to reservoir to be flowed through distribution pipe then to the customers. This condition is in line with IWA's study finding that water catchment coming from both plantation and forest affects negatively the quality of water ${ }^{15}$. It alsoresults in sediment inside water reservoir. WHO's guideline of 2017 states that surface water processing system should be able to achieve less than 0.03 NTU before disinfection ${ }^{7}$.The quality water source is controlled to prevent thecondition and utilization degradation from occurring that will harm the health ${ }^{14}$.

The next event is the opened pipe (score $=16$ ) in distribution pipe and plumbing pipe is on opened and unplanted position. This condition increases the risk of broken pipe and Coliformbacterial contamination in drinking water source. The unplanted pipe is due to piping installation not complying with the required quality standard. The requirement of healthy use for hygiene and sanitation mentions that the pipe should be implanted safely and there may not be cross connection to liquid waste pipe on land surface ${ }^{14}$. Water safety plan includes several aspects, among others: (1) collection or storage, (2) Processing Unit, and (3) Distribution unit constituting piping system distributing water from the processing unit to customers ${ }^{7}$. The system existing in Sawangan Village is different from the one recommended by World Health Organization (WHO), in which there is no water processing activity that will harm the consumers' health.

Table 6 presenting the result of assessment on water safety risk in DWSSMG in Sawangan Village represents the condition of water supplying system today in Gringsing Sub District area of Batang Regency, and it can occur in other regions. About 11 hazardous events (risks) occur in Sawangan Village belonging to quality, quantity, continuity, and accessibility categories. This condition should be controlled and prevented immediately, in order to provide an alternative method to deal with the hazard and the risk, one of which is through validating the alternative controlling measure. This measure is taken to remove or to reduce risk and hazardous event in water supply system to ensure the safe water supply. The procedure of control should be arranged well in order to be reference to the organizer or DWSSMG. A list containing 
some constraints or choices can serve as a useful reserve to a failed measure in order to deal with the hazardous event and the risk successfully. The result of observation on water quality in five Villages in Gringsing Sub District shows that the distribution system has not been equipped with some treatment before reaching the consumers. The good water safety system, according to WHO (world Health Organization)'s guidelines should includes source, treatment, distribution, and consumer ${ }^{16}$.

As presented in Table 1, the risk can be identified in some stages by its probability and severity ${ }^{17}$.

\subsection{Analysis of Water Safety Quantity Risk in DWSSMG in Gringsing Sub District of Batang Regency in 2020}

In this subsection, the analysis on quantity-type risk is conducted based on Table 6. Out of five DWSSMGs existing in Gringsing Sub District, one in Sawangan village shows the decreased water supply in both rainy and dry seasons, in which water flows only 4-5 hours a day, and basic water supply coming from river existing in the forest cannot meet the customers' need for water. The customers also inform that water flows in the evening and the morning only, with alternating system. There are 904 DWSSMGs beneficiaries in Sawangan village. The Minister of Internal Affairs' Regulation about technical guidelines and procedures of regulating water tariff in drinking water local company number 23 of 2006 mentions that the need for water is 60 liter/person/day ${ }^{18}$. In this case, the organizer cannot meet the required quantity to suffice the consumers' need. In such condition, people should meet their need for water by getting water individually from the water source existing in the forest,in which the water safety cannot be ensured. The authors also recommend the village government tosupport the fulfillment of water need using Village fund or by applying for the Regency Allocation fund.

\subsection{Risk Analysis of Water Safety in Continuity Category in DWSSMG in Gringsing Sub District of Batang Regency in 2020}

Continuity,in this subsection, is defined as water flowing continuously anytime without alternating system ${ }^{19}$. The result of identification on five DWSSMGs in Gringsing Sub District shows that only the one in Sawangan Village experiences water flowing discontinuously to the customers. DWSSMG officer also informs the water's flowrate incapable of meeting the customers need for water, 60 liter /person/day ${ }^{18}$. Meanwhile, the condition of water supply flows for $20-<24$ hours per day, belonging to safe category, in Surodadi, Lebo, Tedunan, and Madugowongjati Villages. The constraint found in Sawangan Village is related to water flow rate and supply that cannot meet the customers' need for water. It is because of the uncertain river water source existing in the forest and used by the farmers to irrigate the farm. Primary water source of river belongs to unfeasible basic water source category. Inadequate water supply will potentially lead to water contamination ${ }^{10}$. This condition should be resolved by increasing basic (primary) water source to supply the community as customers.

\subsection{Risk Analysis on the WSP's Accessibility in five DWSSMGs in GringsingSub District of Batang Regency in 2020}

This subsection identifies and presents the result of interview with the members of DWSSMG leadership in five corresponding villages, with the average water price of IDR $1,000 / \mathrm{m}^{3}$ and the result of interview with the representatives of customers indicating that the price is cheap and they should pay IDR25,000-IDR30,000 for water. The authors also conduct a survey of water price in PDAM (Drinking Water Local Company) and finds that the water price in five villages is still less than IDR2500/ $\mathrm{m}^{3}$, meaning that water users in five villages (Surodadi, Tedunan, Sawangan, Madugowongjati, and Lebo) still can pay the price of water managed by KPSPAM.

\subsection{Environment-Based Disease Incidence Condition in PuskesmasGringsing 2 Area}

Water-waste is a disease resulting from poor water cleanliness and becomes a problem because the water available is not sufficient for washing purpose. This disease often develops in mountain area, including typhus, scabies, ear and eye infections ${ }^{1}$. Considering the information acquired from sanitarians of Puskesmas Gringsing 2, Gastritis and Dermatitis belong to 10 top diseases in the area ${ }^{20}$. Gastritis incidence occurs mostly on November, and toward rainy season.

\subsection{The Control of Water Safety Risk incidence in five DWSSMGs in Gringsing Sub District of Batang Regency in 2020}

The control of risk incidence is the follow up of the result of identification of risk incidence. Each incidence can occur more than once. From the database of incidence, the probability scale of hazardous event can be found. The more frequently the incidence occurs, the larger is the probability scale of incidence. Each hazardous event also has risk severity, either highly severe or mild. The more severe the effect of hazardous event risk, the larger is the risk severity scale.

From table 20, it can be seen that considering the control of risk in five DWSSMGs in the villages in Gringsing Sub District of Batang Regency, controlling measure should be taken on Sawangan Village with 8 
water safety risks belonging to high category. This incidence will affect water safety and people's health.

Risk control in Surodadi Village was implemented to 2 high-category risks needing immediate resolution: 1) broken water meter, and 2) the presence of coliform bacterium in house plumbing. These two high-category risks were followed-up by the organizer of DWSSMG in Surodadi Village by communicating the damage and the cost of water meter purchasing to the customers, but it has not been purchased yet because unavailable fund. The broken water meter incidenceleads to water leakage potentially enabling the external bacteria to enter into it. It is indicated with the sample containing Coliform bacterium $85 \mathrm{MPN} / 100 \mathrm{ml}$. The controllingmeasure taken over the presence of bacteria in DWSSMG so far has not used disinfection or chlorination yet, because of limited knowledge and fund. The determinants of successful water safety implementation are technical capacity development, public participation, and monitoring and verification ${ }^{21}$. In addition, the controlling measures taken are to drain reservoir periodically, and to repair the leaked pipe plumbing. Such condition is in line with previous study ${ }^{22}$ finding the presence of coliform bacterium in reservoir and plumbing, because no regular disinfection and draining processes are conducted.

Risk controlling measures taken in Tedunan Village are similar to those in Surodadi Village. One (1) incidence is found where there is Coliform bacterium in reservoirs 1 and 2, and house plumbing, with scores of $468 \mathrm{MPN} / 100$ $\mathrm{ml}, 132 \mathrm{MPN} / 100 \mathrm{ml}$, and $108 \mathrm{MPN} / 100 \mathrm{ml}$, respectively. Supply chain of water source without disinfection process potentially results in Coliform bacteria in house plumbing. Disinfection of basic water source is not conducted due to limited knowledge and fund, so that the controlling measures taken are to repair the leaked tools. Chlorine chemical administration is intended tokill bacteria or hazardous microorganisms contained in the water. Household water disinfection in developing countries is conducted to maintain the residual concentration of water and to protect the customers from post-maintenance andstorage contamination, using hypochlorite $0.5 \%$ and $0.1 \%$. The recommended dose of free chlorination is $2 \mathrm{mg} / \mathrm{liter}$ for clear water (turbidity< 10 nephelometric unit) and 4 $\mathrm{mg} /$ liter for turbid water(turbidity $>10$ nephelometric unit), and residual chlorine of $0.2-0.5 \mathrm{mg} / \mathrm{liter}^{7}$, but it is still becomes the topic of discussion for DWSSMG team as it is related to funding and human resource. Coordination is also established with Puskesmas (Public Health Centers) in Gringsing Sub District, concerning the supervision of water safety that has been done by conducting laboratory test on water periodically.
Risk control in Sawangan Village of Gringsing Sub District, Batang Regency is conducted over 8 (eight) risks belonging to high category. 1) Sediment on the bottom of reservoir is controlled by scheduling the reservoir draining routinely by technical team or operator. It is intended to reduce pathogen or dirt contained in reservoir. Water supply coming from the river and streamed into reservoir without processing activity potentially leads to poor quality of water. It can be seen from the result of quality test on the sample water shown in table 9.

The result of bacteriology test on water in Sawangan Village shows that from the five sampling pointsin water source, the turbidity is found (136 NTU), and Coliform bacterium of $396 \mathrm{MPN} / 100 \mathrm{ml}$ is found in reservoir, it surpasses the threshold, leakage is found in house plumbing, and Coliform bacteria is found in all sampling points with the score surpassing the threshold. It does not meet the requirement specified in Minister of Health's Regulation No.492 of 2010 about water quality, 0MPN/100 $\mathrm{ml}^{5}$.

The control of water safety risk in DWSSMG in Gringsing Sub District of Batang Regency is presented in detail in table 9.

\begin{tabular}{|c|c|c|c|}
\hline Village & $\begin{array}{c}\text { Hazardous } \\
\text { Event }\end{array}$ & $\begin{array}{c}\text { Controlling } \\
\text { Measure }\end{array}$ & $\begin{array}{l}\text { Correcting } \\
\text { Measure }\end{array}$ \\
\hline \multirow[t]{2}{*}{ Surodadi } & $\begin{array}{l}\text { Broken water } \\
\text { meter in SR }\end{array}$ & $\begin{array}{l}\text { Repairing and } \\
\text { changing } \\
\text { water meter in } \\
\text { house } \\
\text { plumbing }\end{array}$ & $\begin{array}{l}\text { Having not } \\
\text { been } \\
\text { conducted } \\
\text { yet, waiting } \\
\text { for fund }\end{array}$ \\
\hline & $\begin{array}{l}\text { Coliform } \\
\text { bacteriumis } \\
\text { found in } \\
\text { reservoir and } \\
\text { reservoirand } \\
\text { SR }\end{array}$ & $\begin{array}{l}\text { Draining } \\
\text { reservoir } \\
\text { periodically }\end{array}$ & $\begin{array}{l}\text { Not } \\
\text { conducted } \\
\text { routinely } \\
\text { yet }\end{array}$ \\
\hline Tedunan & $\begin{array}{l}\text { E.Coli and } \\
\text { total Coliform } \\
\text { in reservoirs } 1 \\
\text { and 2, and } \\
\text { house } \\
\text { plumbing. }\end{array}$ & $\begin{array}{l}\text { Installing } \\
\text { injection for } \\
\text { chlorination in } \\
\text { reservoir } 2\end{array}$ & $\begin{array}{l}\text { Not } \\
\text { conducted } \\
\text { yet due to } \\
\text { limited } \\
\text { human } \\
\text { resource and } \\
\text { fund }\end{array}$ \\
\hline $\begin{array}{c}\text { Sawanga } \\
n\end{array}$ & $\begin{array}{l}\text { Sediment on } \\
\text { the bottom of } \\
\text { reservoir }\end{array}$ & $\begin{array}{l}\text { Constructing } \\
\text { processing } \\
\text { basin before } \\
\text { putting it into } \\
\text { reservoir, and } \\
\text { draining the } \\
\text { reservoir } \\
\text { routinely }\end{array}$ & $\begin{array}{l}\text { Not } \\
\text { conducted } \\
\text { yet due to } \\
\text { limited fund } \\
\text { as it needs } \\
\text { much fund }\end{array}$ \\
\hline
\end{tabular}




\begin{tabular}{|c|c|c|c|}
\hline Village & $\begin{array}{l}\text { Hazardous } \\
\text { Event }\end{array}$ & $\begin{array}{c}\text { Controlling } \\
\text { Measure }\end{array}$ & $\begin{array}{l}\text { Correcting } \\
\text { Measure }\end{array}$ \\
\hline & $\begin{array}{l}\text { Pathogenic } \\
\text { contamination } \\
\text { in reservoir }\end{array}$ & $\begin{array}{l}\text { Preparing } \\
\text { screen or filter } \\
\text { on catching } \\
\text { tub or bar } \\
\text { screen }\end{array}$ & $\begin{array}{l}\text { Not } \\
\text { conducted } \\
\text { optimally } \\
\text { yet optimal }\end{array}$ \\
\hline & $\begin{array}{l}\text { Manure in } \\
\text { reservoir }\end{array}$ & $\begin{array}{l}\text { Preparing } \\
\text { screening on } \\
\text { catching tub } \\
\text { and } \\
\text { constructing } \\
\text { tub to process } \\
\text { the water } \\
\text { before } \\
\text { distribution }\end{array}$ & $\begin{array}{l}\text { Using cloth } \\
\text { to refine the } \\
\text { water }\end{array}$ \\
\hline & $\begin{array}{l}\text { Broken pipe in } \\
\text { plumbing } \\
\text { installation }\end{array}$ & $\begin{array}{l}\text { Repairing and } \\
\text { connecting the } \\
\text { pipes }\end{array}$ & $\begin{array}{l}\text { Having been } \\
\text { conducted } \\
\text { not } \\
\text { optimally } \\
\text { related to the } \\
\text { esthetics of } \\
\text { plumbing }\end{array}$ \\
\hline & Opened pipes & $\begin{array}{l}\text { Repairing and } \\
\text { covering the } \\
\text { opened pipe }\end{array}$ & $\begin{array}{l}\text { Not } \\
\text { conducted } \\
\text { yet because } \\
\text { some pipes } \\
\text { are still } \\
\text { opened and } \\
\text { broken } \\
\text { around the } \\
\text { road }\end{array}$ \\
\hline & $\begin{array}{l}\text { E.Coli and } \\
\text { Coliform } \\
\text { bacteria in } \\
\text { water source } \\
\text { and house } \\
\text { plumbing }\end{array}$ & $\begin{array}{l}\text { Routinely } \\
\text { reservoir } \\
\text { draining and } \\
\text { chlorination } \\
\text { injection }\end{array}$ & $\begin{array}{l}\text { Injection and } \\
\text { chlorination } \\
\text { have not } \\
\text { been } \\
\text { conducted } \\
\text { yet due to } \\
\text { limited } \\
\text { human } \\
\text { resource and } \\
\text { fund }\end{array}$ \\
\hline Lebo & $\begin{array}{l}\text { Sediment on } \\
\text { the bottom of } \\
\text { reservoir }\end{array}$ & $\begin{array}{l}\text { Draining and } \\
\text { injecting and } \\
\text { chlorinating or } \\
\text { disinfecting } \\
\text { routinely }\end{array}$ & $\begin{array}{l}\text { Draining has } \\
\text { been } \\
\text { conducted, } \\
\text { but } \\
\text { chlorination } \\
\text { injection has } \\
\text { not been }\end{array}$ \\
\hline
\end{tabular}

\begin{tabular}{|c|c|c|c|}
\hline Village & $\begin{array}{c}\text { Hazardous } \\
\text { Event }\end{array}$ & $\begin{array}{c}\text { Controlling } \\
\text { Measure }\end{array}$ & $\begin{array}{c}\text { Correcting } \\
\text { Measure }\end{array}$ \\
\hline & & & done yet. \\
\hline & $\begin{array}{l}\text { Opened } \\
\text { unplanted pipe } \\
\text { on distribution } \\
\text { installation }\end{array}$ & $\begin{array}{l}\text { Repairing pipe } \\
\text { and covering } \\
\text { the pipe in } \\
\text { order to be } \\
\text { planted into } \\
\text { the ground }\end{array}$ & $\begin{array}{l}\text { Has been } \\
\text { conducted } \\
\text { less } \\
\text { optimally }\end{array}$ \\
\hline & $\begin{array}{l}\text { Coliform } \\
\text { bacterial } \\
\text { contamination } \\
\text { in leaked } \\
\text { distribution } \\
\text { installation }\end{array}$ & $\begin{array}{l}\text { Repairing } \\
\text { piping } \\
\text { plumbing } \\
\text { correctly }\end{array}$ & $\begin{array}{l}\text { Routine } \\
\text { examination } \\
\text { on water } \\
\text { quality at } \\
\text { least once in } \\
6 \text { months. }\end{array}$ \\
\hline & $\begin{array}{l}\text { Coliform } \\
\text { bacteria in the } \\
\text { broken house } \\
\text { plumbing h }\end{array}$ & $\begin{array}{l}\text { Repairing } \\
\text { house } \\
\text { plumbing }\end{array}$ & $\begin{array}{l}\text { Routine } \\
\text { examination } \\
\text { of water } \\
\text { quality at } \\
\text { least once in } \\
6 \text { (six) } \\
\text { months }\end{array}$ \\
\hline
\end{tabular}

Considering the evaluation on risk control as shown in table 9 and referring to World Health Organization (WHO)'s handbook of water safety plan of 2017, the next stage is evaluating and monitoring the team ${ }^{7}$. Due to limited research period, evaluating and correcting measures have not been taken yet to reduce the water safety risk in DWSSMG in Gringsing Sub District of Batang Regency in this research in 2020, but it is put into recommendation section. The effort of correcting the result of identification and risk assessment should be done well and mitigated correctly, as a measure to reduce water safety risk.

\section{CONCLUSION}

The map of water safety risk condition in DWSSMG in Gringsing Sub District of Batang Regency in 2020 indicates that Sawangan Village belongs to high risk category, Lebo to Medium, and Tedunan, Surodadi, and Madugowongjati to low risk category. Quality, quantity, and continuity conditions of drinking water in Sawangan Village belong to high risk category that will harm the health, whileto ensure the water safety, DWSSMG should take some correcting measures: a) repairing the basic water source for drinking water processing, b) scheduling reservoir draining periodically, c) providing filter on catching tub, d) repairing the connection in distribution and plumbing pipes, e) chlorination in reservoir, and f) increasing basic water source. Meanwhile, the correcting 
measures taken in Lebo Village are: a) scheduling reservoir draining, b) disinfection or chlorination, c) training for reinforcing WSP in DWSSMG.

\section{ACKNOWLEDGEMENTS}

The authors express their gratitude to DWSSMG in Surodadi, Tedunan, Madugowongjati, Sawangan, and Lebo Villages of Gringsing Sub District, Batang Regency, Health Service Office of Batang Regency, Public Work and Spatial Layout Service Office of Batang Regency, Puskesmas Gringsing of Batang Regency for helping complete the evaluative research on the water safety plan in DWSSMG in Gringsing Sub District of Batang Regency well.

\section{REFERENCES}

[1] WHO. Guidelines for Drinking-water Quality Fourth Edition WHO Library Cataloguing-in-Publication Data. World Health Organisation (2011).

[2] Kesehatan, K. K. R. I. Pencapaian Indikator PASD. (2021).

[3] Kementrian PPN/ Bappenas. Rancangan Rencana Pembangunan Jangka Menengah Nasional 2020-2024. Rencana Pembangunan Jangka Menengah Nasional 20202024 (2019).

[4] Pemerintah Indonesia. Peraturan Pemerintah Republik Indonesia Nomor 122 Tahun 2015 Tentang Sistem Penyediaan Air Minum. Standar Pelayanan Minimal (2015).

[5] Kementrian Kesehatan Republik Indonesia. Peraturan Menteri Kesehatan Republik Indonesia Nomor 492/Menkes/Per/IV/2010 Tentang Persyaratan Kualitas Air Minum. Peraturan Mentri Kesehatan Republik Indonesia (2010).

[6] Bartam, J.Corrales.L, Davison.A, Deere.D, Drury.D, Gordon.B, Howard.G.Rinehold.A, S. . Water Safety Plan Manual Step by step risk management for drinking suppliers. (World Health Organization, 2009).

[7] World Health Organization. Guidelines for Drinking Water Quality Fourth Edition Incoporationg the First Addendum. (WHO Library Cataloguing in Publication Data, 2017).

[8] Mullenger, J., Ryan, G. \& Hearn, J. A water authority's experience with HACCP. Water Sci. Technol. Water Supply2, 149-155 (2002).

[9] Cotruvo, J. A. 2017 Who guidelines for drinking water quality addendum. Journal - American Water Works Association (2017).

[10] World Health Organization. Guidelines for drinking-water quality: fourth edition incorporating the first addendum. (2017).

[11] Abuzerr, S. et al. Comprehensive Risk Assessment of Health-Related Hazardous Events in the Drinking Water Supply System from Source to Tap in Gaza Strip, Palestine. J. Environ. Public Health2020, 10 (2020).

[12] BAPPENAS. Pedoman Pengukuran Capaian Pembangunan Perumahan dan Pemukiman Berbasis Hasil (Outcome). (2019).

[13] Naschitz, J. E. et al.Patterns of hypocapnia on tilt in patients with fibromyalgia, chronic fatigue syndrome, nonspecific dizziness, and neurally mediated syncope. American Journal of the Medical Sciences vol. 331 (2006).

[14] Menteri Kesehatan Republik Indonesia. Peraturan Menteri Kesehatan Republik Indonesia Nomor 32 Tahun 2017 Tentang Standar Baku Mutu Kesehatan Lingkungan Dan Persyaratan Kesehatan Air Untuk Keperluan Higiene Sanitasi, Kolam Renang, Solus Per Aqua dan Pemandian Umum. Peratur. Menteri Kesehat. Republik Indones. 1-20 (2017).

[15] Publishing, I. W. A. Water safety planning and implementation: lessons from South Africa Mthokozisi Ncube and Maxwell N . Pawandiwa. 557-563 (2013) doi:10.2166/washdev.2013.209.

[16] Bartam, J.Corrales.L, Davison.A, Deere.D, Drury.D, Gordon.B, Howard.G.Rinehold.A, S. . Water safety plan manual: step by step risk management for Drinking-water supliers. (World Health Organization, 2009).

[17] Aghaei, M. et al. Risk assessment of water supply system safety based on WHO water safety plan; case study: Ardabil, Iran. Desalin. Water Treat.80, (2017).

[18] Permendagri. Peraturan Menteri dalam Negeri Nomor 23 Tahun 2006 tentang Pedoman Teknis dan Tatacara Pengaturan Tarif Air Minum pada Perusahaan Daerah Air Minum. (2006) doi:10.16258/j.cnki.16745906.2006.01.022.

[19] Satuan Kerja Direktorat Pengembangan Air Minum. Rencana Pengamanan Air Minum(RPAM) Manual:Perencanaan,Implementasi,dan MonitoringEvaluasi. (Direktorat Jenderal Ciptakarya Kementrian Pekerjaan Umum, 2012).

[20] Kabupaten, D. K. Profil Dinas Kesehatan Kabupaten Batang. in (2019).

[21] Mälzer, H. J., Staben, N., Hein, A. \& Merkel, W. Identification, assessment, and control of hazards in water supply: Experiences from water safety plan implementations in Germany. Water Sci. Technol.61, 1307-1315 (2010).

[22] Budiyono et al. Risk Assessment of Drinking Water Supply System in the Tidal Inundation Area of Semarang Indonesia. Procedia Environ. Sci. (2015) doi:10.1016/j.proenv.2015.01.014. 